\title{
NANOPARTICLE-BASED WORLD - ORIGIN OF LIFE THEORY
}

\author{
Lukas NEJDL, Kristyna ZEMANKOVA, Kristyna PAVELICOVA, Eliska SEDLACKOVA, \\ Marketa LUKLOVA, Vojtech ADAM, Marketa VACULOVICOVA
}

\author{
Department of Chemistry and Biochemistry, Mendel University in Brno, Czech Republic, EU, \\ LukasNejdl@gmail.com
}

https://doi.org/10.37904/nanocon.2020.3723

\begin{abstract}
Many theories are currently being accepted as possible explanations for the origins of life on early Earth (e.g. Metabolism-first world, Zinc world, Thioester world, RNA world and others). However, discovered enzymemimetic properties of nanoparticles may lead to reconsideration of these theories. Recently, we postulated that one of the stages of chemical evolution could have been associated with nanozymatic activity of different nanoparticles that could form primitive prebiotic photodynamic redox chemical networks with proto-enzymatic activity. Our theory (Nanoparticle-based World) assumes that chemical evolution passed through the nanoparticle-assisted stage and could have led to sustainable metabolism. Formamide-based prebiotic chemistry assumes that formamide could have accumulated in sufficient amounts to serve as a feedstock and reaction medium for the synthesis of the first biogenic molecules. In this work, UV-induced formation (prebiotic scenario) of nanoparticles with xanthine oxidase like activity was demonstrated. All reactants (thiol-containing compounds, metals ions - zinc and cadmium, ammonia and fomamide) were highly probably present on early Earth.
\end{abstract}

Keywords: Nanoparticles, formamide, Origin of life, UV radiations, metal ions, thiols

\section{INTRODUCTION}

Many theories like Metabolism-first world [1], Zinc world [2], Thioester world [3], RNA world [4], Lipid world [5] and others, are currently being considered the explanation of the origin of life on Earth. Scientists all around over the world still discuss the physical and chemical conditions on early Earth, sources of energy, the feedstock molecules and transformation of non-living matter (biogenic building blocks) to self-sustaining autocatalytic networks (sustainable life). We believe that all the right places for the emergence of life contained mainly sulfur (especially thiols), metals ions, ammonia, and formamide environment. Formamide-based prebiotic chemistry assumes that formamide could accumulate in high enough amounts to serve as a feedstock and reaction medium for the synthesis of the first biogenic molecules like nucleobases, nucleosides, amino acids, sugars, amino sugars, carboxylic acids and others [6]. In our previous work, we showed that thermal treatment $\left(160{ }^{\circ} \mathrm{C}, 24\right.$ hours) of formamide in presence of various clays (Ni/Fe meteoritic material, $\mathrm{Fe}_{2} \mathrm{O}_{3}$ ) caused formation of adenine, guanine, cytosine, thymine, uracil, purine, urea, hypoxanthine, guanidine and glycine [7]. In this work, we proved that formamide (50\%) is a great solvent (environment) for UV-induced formation of $\mathrm{ZnCd}$ quantum dots (QDs) from very simple mixture of precursors containing thiols (e.g. mercaptosuccinic acid), metals ions $\left(\mathrm{Zn}^{2+}\right.$ and $\mathrm{Cd}^{2+)}$ and ammonia $\left(\mathrm{NH}_{3}\right.$, in range $\left.0-2 \%\right)$. Also it was proved that these $\mathrm{ZnCd}$ QDs mimic enzyme xanthine oxidase $(\mathrm{XO})$ under visible light conditions. And that is why we assume that first proto-metabolism pathway could have been associated with purine proto-metabolism catalyzed by nanoparticles (nanozymes). Caetano-Anolles $\mathrm{G}$. et al. strongly suggested that first metabolic pathway in prebiotic chemistry was related to the synthesis of nucleotides for the RNA world, which was linked to the purine metabolic subnetwork [8]. Sun M. et al. showed that CdTe QDs can specifically recognize and cleave the restriction site GATATC in double-stranded DNA, mimicking an enzyme restriction endonuclease 
[9]. These findings support the assumption that abiotic artificial materials (nanozymes) were apparently connected to the RNA world. The functions of ribozymes in modern organisms support the hypothesis that life passed through an RNA world before the emergence of proteins or DNA. Moreover, numerous microorganisms are capable of nanoparticle synthesis in order to remove undesired metal species [10-14]. This ability of microorganisms can also support the hypothesis that chemical evolution of life passed through the abiotic artificial material (nanozymes). Nanozymes as alternatives to natural enzymes excel mainly due to their stability, chemical diversity, and functionality in non-aqueous solvents [15]. Currently, nanozymes are prepared mainly from metal or carbon materials [16]. The enzymatic activity of inorganic materials starts to be considered highly important in the context of the new theories about the origin of life [17-19]. In this work, we present and discuss one of the possible scenarios of prebiotic preparation of $\mathrm{ZnCd}$ QDs nanozymes (mimic XO under visible light) with connection to first proto-metabolism based on purines catabolism in formamide environment. Figure 1 represents a graphical summary (timeline) of main events related to the enzymes, ribozymes and nanozymes in origin of life context.

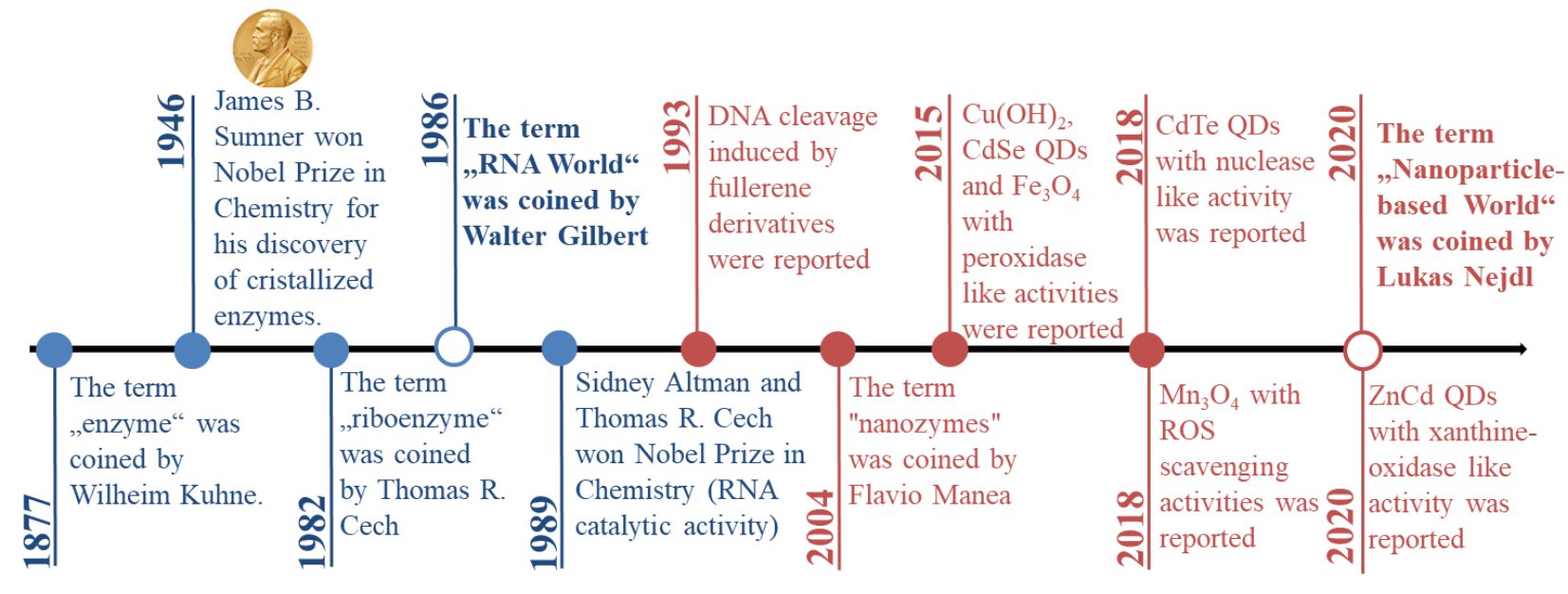

Natural enzymes Nanozymes

Figure 1 Represents a graphical summary of main events related to the natural enzymes and nanozymes in origin of life context according $[9,19,20]$

\section{MATERIALS AND METODS}

\subsection{Chemicals}

Standards and other chemicals were purchased from Sigma-Aldrich (St. Louis, MO, USA) in ACS purity.

\subsection{Precursors preparation, UV- irradiation and fluorescence analysis}

Stock solutions of $16 \mathrm{mM}$ mercaptosuccinic acid (MSA), $6 \mathrm{mM}$ zinc(II) acetate, $6 \mathrm{mM}$ cadmium(II) acetate, $15 \%$ ammonia $\left(\mathrm{NH}_{3}\right)$ were prepared in distilled water and stored at $4{ }^{\circ} \mathrm{C}$. Next, $12.5 \mu \mathrm{L}$ of zinc(II) acetate, 12.5 $\mu \mathrm{L}$ of cadmium(II) acetate, $12.5 \mu \mathrm{L}$ of MSA, $12.5 \mu \mathrm{L}$ of $15 \%, 7.5 \%, 3.7 \%, 1.8 \%$ and $0 \% \mathrm{NH}_{3}$ were pipetted into the five neighboring wells of a UV-transparent 96-wellplate with a flat bottom by CoStar (Corning, USA) and subsequently $50 \mu \mathrm{L}$ of $99.5 \%$ formamide was added to each well. A total volume of the samples was $100 \mu \mathrm{L}$ each. Subsequently, the plate was placed into the UV transilluminator (Vilber Lourmat, Marne-la-Vallee Cedex, France) with $\lambda_{\mathrm{em}}=254 \mathrm{~nm}$ and irradiated for 0 and 5 minutes. The sample area of $20 \times 20 \mathrm{~cm}$ was illuminated by 6 emitting tubes with power of $15 \mathrm{~W}$ each. Finally, wavelength of $350 \mathrm{~nm}$ was used for fluorescence excitation and the emission scan was measured within the range from 380 to $800 \mathrm{~nm}$ by Tecan Infinite $200 \mathrm{M}$ PRO (TECAN, Switzerland). 


\subsection{Enzymatic reactions}

Xanthine oxidase-like activity of ZnCd QDs after visible light irradiation by table 6800K (6W) LED lamp (EMOS, Prerov, Czech Republic) was investigated by highly water-soluble tetrazolium salt that produces a formazan dye upon reduction with a superoxide anion. The reaction was monitored at $440 \mathrm{~nm}$ by UV/Vis spectrophotometer Tecan Infinite 200 M PRO (TECAN, Switzerland) using UV-transparent 96 wellplate with a flat bottom by CoStar (Corning, USA). The signal intensity was proportionate to the amount of superoxide anion. Standard enzyme of xanthine oxidase (positive control) was purchased from Sigma-Aldrich.

\section{RESULTS AND DISCUSSION}

The hydrogen cyanide ( $\mathrm{HCN})$ is most abundant three-atoms compound in interstellar environment and together with three-atoms water $\left(\mathrm{H}_{2} \mathrm{O}\right)$ formed formamide $\left(\mathrm{CHONH}_{2}\right)$ [6]. Codella $\mathrm{C}$. et al proved according interferometric measurement that formamide (potentially crucial building block of life [21-24]) is efficiently formed in the gas phase around Sun-like protostars [25]. The formamide has been also detected in comets, in the solid phase on grains around the young stellar object, in the galactic center sources Sagittarius and in the interstellar medium [26-30]. This work was focused on one-pot synthesis of the ZnCd QDs in formamide environment and subsequently investigation of their proto-metabolic activity (mimicking enzymes - xanthine oxidases). Photo-chemical processes leading to formation of the $\mathrm{ZnCd}$ QDs are described in our previous work [31].

\subsection{Synthesis of ZnCd QDs in formamide solution and spectroscopic evaluation of ZnCd QDs xanthine oxidase activity}

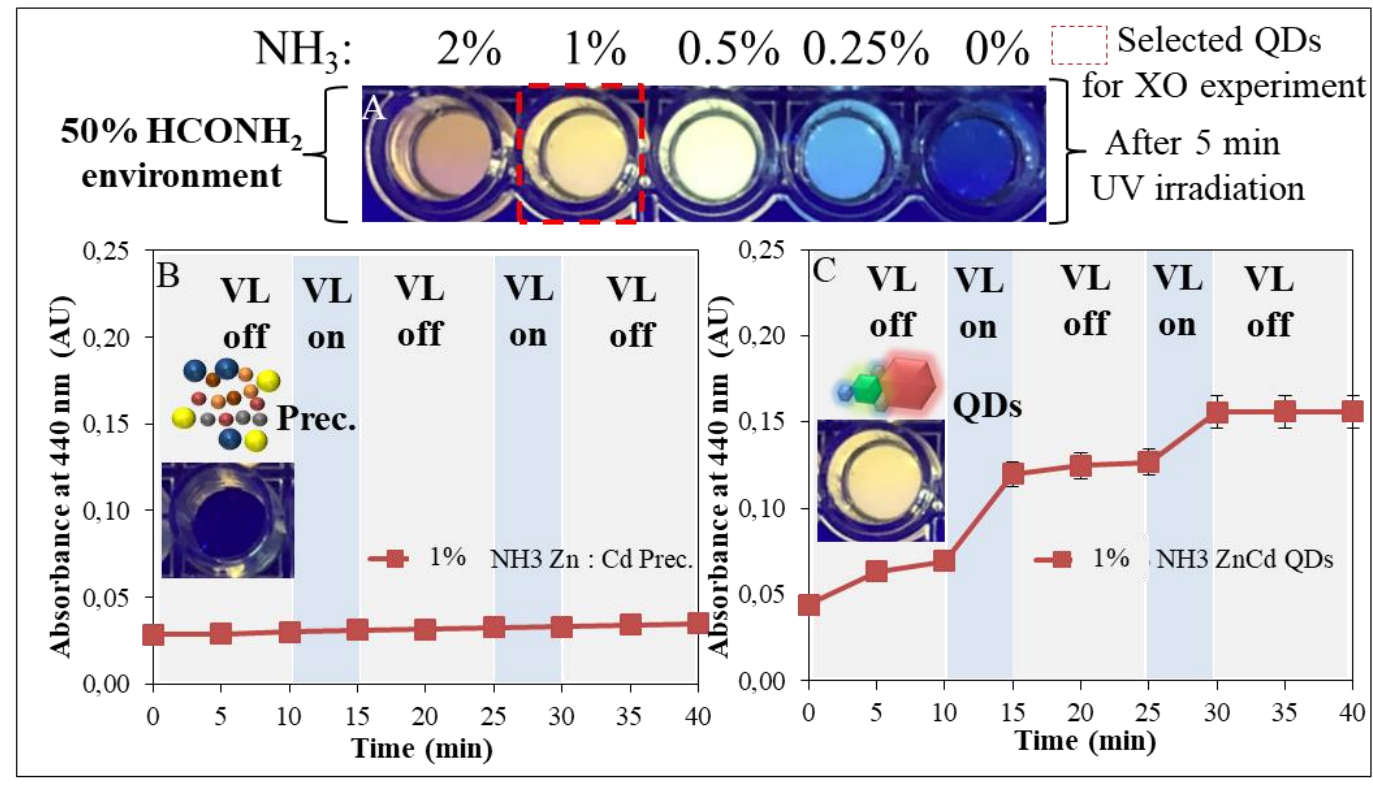

Figure 2 A) Precursors $(0.75 \mathrm{mM}$ cadmium acetate, $0.75 \mathrm{mM}$ zinc acetate, $2 \mathrm{mM}$ mercaptosuccinic acid and ammonia solution in range $0-2 \%$ ) were irradiated for 5 minutes by UV and then a real photo was taken. Monitoring of dependence of absorbance at $\lambda=440 \mathrm{~nm}$ on (B) precursors and (C) ZnCd QDs exposure by visible light in substrate for determination of $\mathrm{XO}$ activity.

Several plausible scenarios involve prebiotic reactions in warm mineral and metal rich environment (involving mainly $\mathrm{Fe}, \mathrm{Cu}$ but also $\mathrm{Zn}, \mathrm{Cd}, \mathrm{Ag}$, $\mathrm{Co}, \mathrm{Ni}, \mathrm{Pb}, \mathrm{Mo}$ etc. [32,33] and their combination with chemistries of sulfiderich hydrothermal vents [34] or lagoons exposed to UV radiation [35]. Here, the UV-induced reaction was studied in $50 \%$ formamide environment. Formamide-based prebiotic chemistry suggests a plausible reaction route for the synthesis of nucleobases and others biogenic molecules [36]. Therefore, we have tested the 
suitability of formamide environment (50\%) for prebiotic formation of ZnCd QDs by evaluation of fluorescence properties of $\mathrm{ZnCd}$ QDs formed from the mixture of precursors $(0.75 \mathrm{mM}$ cadmium acetate, $0.75 \mathrm{mM}$ zinc acetate, $2 \mathrm{mM}$ mercaptosuccinic acid and 0, 0.25,0.5,1 and $2 \%$ ammonia solution) after 5 minute UV irradiation $\left(\lambda_{\mathrm{em}}=254 \mathrm{~nm}\right)$. The red shift of $\mathrm{ZnCd}$ QDs was observed by increasing of the ammonia concentration as can be seen in Figure 2 A. It was proved that formamide is a suitable solvent (environment) for UV-induced synthesis of ZnCd QDs. Subsequently from previous experiment was chosen ZnCd QDs containing 1\% ammonia (marked with a red square, Figure 2 A) and mixed together with substrate (tetrazolium salt) for monitoring of xanthine oxidase (XO) activity. Also unirradiated precursors of $\mathrm{ZnCd}$ QDs were mixed together with substrate. XO-like activity of $\mathrm{ZnCd}$ QDs was investigated by tetrazolium salt that produces a formazan dye upon reduction with a superoxide anion generated by XO or ZnCd QDs. The time dependence of the XOlike activity under visible light (VL) is demonstrated in Figure 2 B (unirradiated precursors) and Figure 2 C ( $\mathrm{ZnCd} \mathrm{QDs}$ ). According to the results it is evident, that the $\mathrm{VL}$ induces $\mathrm{XO}$ activity in case $\mathrm{ZnCd}$ QDs. Formamide-based prebiotic chemistry together with formation of $\mathrm{ZnCd} Q \mathrm{QDs}$ (mimicking enzyme $\mathrm{XO}$ ) could be associated with first self-sustaining autocatalytic networks.

\section{CONCLUSION}

The present work demonstrates that formamide is an excellent solvent (environment) for light (UV)-driven synthesis of ZnCd QDs in the whole spectral range (emission from blue to red). Also, it was proved that $\mathrm{ZnCd}$ QDs mimic enzyme xanthine oxidase under visible light irradiation. We believe that all the cellular subsystems could have arisen simultaneously through common formamide-based chemistry and the key reaction steps could have been driven by light. Therefore, we assume that first proto-metabolism pathway could be associated with purine catabolism provided by nanoparticles (nanozymes) like QDs or other types of nanoparticles/nanomaterials. All precursors (metals ions, sulfur-containing compounds and ammonia), together with formamide, are abundantly represented in space environment. We suggest named all these nanoparticle-mediated reactions in the context origin of life as Nanoparticle-based world [36].

\section{ACKNOWLEDGEMENTS}

\section{The research was founded by the Internal Grant Agency of Mendel University in Brno IGA MENDELU 2019_TP_009.}

\section{REFERENCES}

[1] VASAS, V.,SZATHMARY, E.,SANTOS, M. Lack of evolvability in self-sustaining autocatalytic networks constraints metabolism-first scenarios for the origin of life. Proceedings of the National Academy of Sciences of the United States of America. 2010, vol. 107. no. 4, pp. 1470-1475.

[2] MULKIDJANIAN, A. Y. On the origin of life in the zinc world: I. Photosynthesizing, porous edifices built of hydrothermally precipitated zinc sulfide as cradles of life on earth. Biology Direct. 2009, vol. 4., p. 38.

[3] DEDUVE, C. The thioester world. In: TRANTHANHVAN, J.; TRANTHANHVAN K.; MOUNOLOU J. C.; SCHNEIDER J.; MCKAY C., eds. Frontiers of life. Dreux: Editions Frontieres, 1992.

[4] GILBERT, W. Origin of life - the rna world. Nature. 1986, vol. 319. no. 6055, pp. 618-618.

[5] SEGRE, D.,BEN-ELI, D.,DEAMER, D. W.,LANCET, D. The lipid world. Origins of Life and Evolution of the Biosphere. 2001, vol. 31. no. 1-2, pp. 119-145.

[6] SALADINO, R.,CRESTINI, C.,PINO, S.,COSTANZO, G.,DI MAURO, E. Formamide and the origin of life. Physics of Life Reviews. 2012, vol. 9. no. 1, pp. 84-104.

[7] PASTOREK, A.,HRNCIROVA, J., JANKOVIC, L., NEJDL, L., CIVIS, S., IVANEK, O., SHESTIVSKA, V., KNIZEK, A., KUBELIK, P., SPONER, J., PETERA, L., KRIVKOVA, A., CASSONE, G., VACULOVICOVA, M., SPONER, J. E., FERUS, M. Prebiotic synthesis at impact craters: The role of fe-clays and iron meteorites. Chemical Communications. 2019, vol. 55. no. 71, pp. 10563-10566. 
[8] CAETANO-ANOLLES, G., KIM, H. S., MITTENTHAL, J. E. The origin of modern metabolic networks inferred from phylogenomic analysis of protein architecture. Proceedings of the National Academy of Sciences of the United States of America. 2007, vol. 104. no. 22, pp. 9358-9363.

[9] SUN, M. Z., XU, L. G., QU, A. H., ZHAO, P., HAO, T. T., MA, W., HAO, C. L., WEN, X. D., COLOMBARI, F. M., DE MOURA, A. F., KOTOV, N. A., XU, C. L., KUANG, H. Site-selective photoinduced cleavage and profiling of DNA by chiral semiconductor nanoparticles. Nature Chemistry. 2018, vol. 10. no. 8, pp. 821-830.

[10] LIU, X., GAO, H., WARD, J. E., LIU, X., YIN, B., FU, T., CHEN, J., LOVLEY, D. R., YAO, J. Power generation from ambient humidity using protein nanowires. Nature. 2020, vol. 578, no. 7796, pp. 550-554.

[11] YAN, Z. Y., QIAN, J., GU, Y. Q., SU, Y. L., AI, X. X., WU, S. M. Green biosynthesis of biocompatible cdse quantum dots in living escherichia coli cells. Materials Research Express. 2014, vol. 1., no. 1, p. 14.

[12] SHAO, M., ZHANG, R., WANG, C., HU, B., PANG, D. W., XIE, Z. X. Living cell synthesis of cdse quantum dots: Manipulation based on the transformation mechanism of intracellular se-precursors. Nano Research. 2018, vol. 11. no. 5, pp. 2498-2511.

[13] WU, R. R., WANG, C., SHEN, J. S., ZHAO, F. A role for biosynthetic cds quantum dots in extracellular electron transfer of saccharomyces cerevisiae. Process Biochemistry. 2015, vol. 50. no. 12, pp. 2061-2065.

[14] TILLEY, R. D.,CHEONG, S. Earthworms lit with quantum dots. Nature Nanotechnology. 2013, vol. 8. no. 1, pp. 67.

[15] WEI, H., WANG, E. K. Nanomaterials with enzyme-like characteristics (nanozymes): Next-generation artificial enzymes. Chemical Society Reviews. 2013, vol. 42. no. 14, pp. 6060-6093.

[16] WU, J. J. X., WANG, X. Y., WANG, Q., LOU, Z. P., LI, S. R., ZHU, Y. Y., QIN, L., WEI, H. Nanomaterials with enzyme-like characteristics (nanozymes): Next-generation artificial enzymes (ii). Chemical Society Reviews. 2019, vol. 48. no. 4, pp. 1004-1076.

[17] WALtHER, R., WINTHER, A. K., FRUERGAARD, A. S., VAN DEN AKKER, W., SORENSEN, L., NIELSEN, S. M., OLESEN, M. T. J., DAI, Y. T., JEPPESEN, H. S., LAMAGNI, P., SAVATEEV, A., PEDERSEN, S. E. L., FRICH, C. K., VIGIER-CARRIERE, C., LOCK, N., SINGH, M., BANSAL, V., MEYER, R. L., ZELIKIN, A. N. Identification and directed development of non-organic catalysts with apparent pan-enzymatic mimicry into nanozymes for efficient prodrug conversion. Angewandte Chemie-International Edition. 2019, vol. 58. no. 1, pp. 278-282.

[18] HAZEN, R. M., SVERJENSKY, D. A. Mineral surfaces, geochemical complexities, and the origins of life. Cold Spring Harbor Perspectives in Biology. 2010, vol. 2. no. 5, p. 21.

[19] NEJDL, L., ZEMANKOVA, K., HAVLIKOVA, M., BURESOVA, M., HYNEK, D., XHAXHIU, K., MRAVEC, F., MATOUSKOVA, M., ADAM, V., FERUS, M., KAPUS, J., VACULOVICOVA, M. Uv-induced nanoparticlesformation, properties and their potential role in origin of life. Nanomaterials. 2020, vol. 10. no. 8, pp. 14.

[20] WANG, X. Y., HU, Y. H., WEI, H. Nanozymes in bionanotechnology: From sensing to therapeutics and beyond. Inorganic Chemistry Frontiers. 2016, vol. 3. no. 1, pp. 41-60.

[21] SALADINO, R., CAROTA, E., BOtTA, G., KAPRALOV, M., TIMOSHENKO, G. N., ROZANOV, A. Y., KRASAVIN, E., DI MAURO, E. Meteorite-catalyzed syntheses of nucleosides and of other prebiotic compounds from formamide under proton irradiation. Proceedings of the National Academy of Sciences of the United States of America. 2015, vol. 112, no. 21, pp. E2746-E2755.

[22] PIETRUCCI, F., SAITTA, A. M. Formamide reaction network in gas phase and solution via a unified theoretical approach: Toward a reconciliation of different prebiotic scenarios. Proceedings of the National Academy of Sciences of the United States of America. 2015, vol. 112, no. 49, pp. 15030-15035.

[23] SALADINO, R., DI MAURO, E., GARCIA-RUIZ, J. M. A universal geochemical scenario for formamide condensation and prebiotic chemistry. Chemistry-a European Journal. 2019, vol. 25, no. 13, pp. 3181-3189.

[24] SPONER, J. E., SZABLA, R., GORA, R. W., SAITTA, A. M., PIETRUCCI, F., SAIJA, F., DI MAURO, E., SALADINO, R., FERUS, M., CIVIS, S., SPONER, J. Prebiotic synthesis of nucleic acids and their building blocks at the atomic level - merging models and mechanisms from advanced computations and experiments. Physical Chemistry Chemical Physics. 2016, vol. 18, no. 30, pp. 20047-20066.

[25] CODELlA, C., CECCARELlI, C., CASElLI, P., BALUCANI, N., BARONE, V., FONTANI, F., LEFLOCH, B., PODIO, L., VITI, S., FENG, S., BACHILLER, R., BIANCHI, E., DULIEU, F., JIMENEZ-SERRA, I., HOLDSHIP, J., 
NERI, R., PINEDA, J. E., PON, A., SIMS, I., SPEZZANO, S., VASYUNIN, A. I., ALVES, F., BIZZOCCHI, L., BOTTINELLI, S., CAUX, E., CHACON-TANARRO, A., CHOUDHURY, R., COUTENS, A., FAVRE, C., HILYBLANT, P., KAHANE, C., AL-EDHARI, A. J., LAAS, J., LOPEZ-SEPULCRE, A., OSPINA, J., OYA, Y., PUNANOVA, A., PUZZARINI, C., QUENARD, D., RIMOLA, A., SAKAI, N., SKOUTERIS, D., TAQUET, V., TESTI, L., THEULE, P., UGLIENGO, P., VASTEL, C., VAZART, F., WIESENFELD, L., YAMAMOTO, S. Seeds of life in space (solis) ii. Formamide in protostellar shocks: Evidence for gas-phase formation. Astronomy \& Astrophysics. 2017, vol. 605, p. 7.

[26] DESPOIS, D., CROVISIER, J., BOCKELEE-MORVAN, D., BIVER, N. Comets and prebiotic chemistry: The volatile component. In: LACOSTE, H., ed. Proceedings of the second european workshop on exo-astrobiology. Noordwijk: Esa Publications Division C/O Estec, 2002, vol. 518.

[27] BOCKELEE-MORVAN, D., LIS, D. C., WINK, J. E., DESPOIS, D., CROVISIER, J., BACHILLER, R., BENFORD, D. J., BIVER, N., COLOM, P., DAVIES, J. K., GERARD, E., GERMAIN, B., HOUDE, M., MEHRINGER, D., MORENO, R., PAUBERT, G., PHILLIPS, T. G., RAUER, H. New molecules found in comet c/1995 o1 (hale-bopp) - investigating the link between cometary and interstellar material. Astronomy \& Astrophysics. 2000, vol. 353. no. 3, pp. 1101-1114.

[28] LIS, D. C., MEHRINGER, D. M., BENFORD, D., GARDNER, M., PHILLIPS, T. G., BOCKELEE-MORVAN, D., BIVER, N., COLOM, P., CROVISIER, J., DESPOIS, D., RAUER, H. New molecular species in comet c/1995 o1 (hale-bopp) observed with the caltech submillimeter observatory. Earth Moon and Planets. 1997, vol. 78. no. 1-3, pp. 13-20.

[29] SCHUtTE, W. A., BOOGERT, A. C. A., TIELENS, A., WHITTET, D. C. B., GERAKINES, P. A., CHIAR, J. E., EHRENFREUND, P., GREENBERG, J. M., VAN DISHOECK, E. F., DE GRAAUW, T. Weak ice absorption features at 7.24 and $7.41 \mathrm{mu} \mathrm{m}$ in the spectrum of the obscured young stellar object $\mathrm{w} 33 \mathrm{a}$. Astronomy \& Astrophysics. 1999, vol. 343, no. 3, pp. 966-976.

[30] SOLOMON, P. M. Interstellar molecules. Physics Today. 1973, vol. 26, no. 3, pp. 32-40.

[31] NEJDL, L. Z., K., HAVLIKOVA, M., BURESOVA, M., HYNEK, D., XHAXHIU, K., MRAVEC, F., MATOUSKOVA, M., ADAM, V., FERUS, M., KAPUS, J., VACULOVICOVA, M. Uv-induced nanoparticles-formation, properties and their potential role in origin of life. Nanomaterials. 2020, vol. 10, no. 1529.

[32] KUMAR, A., SHARMA, R., KAMALUDDIN. Formamide-based synthesis of nucleobases by metal(ii) octacyanomolybdate(iv): Implication in prebiotic chemistry. Astrobiology. 2014, vol. 14, no. 9, pp. 769-779.

[33] BIZZARRI, B. M., BOTTA, L., PEREZ-VALVERDE, M. I., SALADINO, R., DI MAURO, E., GARCIA-RUIZ, J. M. Silica metal oxide vesicles catalyze comprehensive prebiotic chemistry. Chemistry-a European Journal. 2018, vol. 24. no. 32, pp. 8126-8132.

[34] KITADAI, N., NAKAMURA, R., YAMAMOTO, M., TAKAI, K., YOSHIDA, N., OONO, Y. Metals likely promoted protometabolism in early ocean alkaline hydrothermal systems. Science Advances. 2019, vol. 5. no. 6, p. 9.

[35] PATEL, B. H., PERCIVALlE, C., RITSON, D. J., DUFFY, C. D., SUTHERLAND, J. D. Common origins of rna, protein and lipid precursors in a cyanosulfidic protometabolism. Nature Chemistry. 2015, vol. 7. no. 4, pp. 301 307.

[36] SPONER, J. E., MLADEK, A., SPONER, J., FUENTES-CABRERA, M. Formamide-based prebiotic synthesis of nucleobases: A kinetically accessible reaction route. Journal of Physical Chemistry A. 2012, vol. 116. no. 1, pp. $720-726$ 